\title{
Severe, unusual, and recurrent infections in rheumatoid arthritis
}

\author{
E. C. HUSKISSON* AND F. DUDLEY HART \\ From the Department of Rheumatology, Westminster Hospital, London
}

Infection has been recognized as an important cause of death in patients with rheumatoid arthritis (Cobb, Anderson, and Bauer, 1953). During the course of the disease, pyarthroses and superficial abscesses have been described (Kellgren, Ball, Fairbrother, and Barnes, 1958) and an increased incidence of respiratory infections has been reported (Kay, 1967; Walker, 1967). We have seen a number of patients with severe and unusual infections and report our experience to emphasize the importance of this complication.

\section{Material}

Details of the twelve patients are shown in Table I and of their 24 infections in Table II. Pyarthroses have not been included unless they were combined with other types of infection or occurred in patients who had other infective episodes.

\section{Observations}

The patients in this series tended to have severe rheumatoid arthritis and all were or became seropositive, mostly at a high titre. Three of the eight patients tested had a positive L.E.-cell test; this may have some significance, though previous authors have not found evidence of more severe disease or a higher incidence of systemic involvement in such patients
(Goldfine, Stevens, Mais, and Shulman, 1965). Six of the twelve patients were receiving steroid therapy at the time of their first infective episode.

No particular sites of infection were favoured and a variety of organisms was found, Staph. aureus accounting for only about half. Pyrexia and a leucocytosis were usual but not invariable findings. Four patients died, one from her sixth infective episode.

Only one patient in the series had Felty's syndrome, a condition in which infection is particularly common.

Case 11, a woman now aged 64, with severe rheumatoid arthritis, started corticosteroid therapy in the tenth year of her illness in 1956. A year later splenomegaly was first noted, and in 1960 neutropenia and recurrent infections became apparent, and her condition deteriorated. Both her spleen and a small splenunculus were removed in 1962. The blood picture rapidly improved, infections ceased to be a trouble, and her arthritis improved considerably, but 4 years later she became ill again with neutropenia and left-sided abdominal pain. 2 months later fullness in the left flank appeared, a perinephric abscess (Episode 22) was drained and the white cell count rapidly returned to normal.

In 1968 a large lung abscess developed (Episode 23) which drained naturally and resolved without operation, on cloxacillin and ampicillin and an increase in corticosteroid therapy.

Table I Particulars of twelve patients

\begin{tabular}{|c|c|c|c|c|c|c|}
\hline Patient no. & Age (yrs) & Sex & Duration of disease & Reciprocal Waaler-Rose titre & L.E. cells & Steroid therapy \\
\hline 1 & 41 & $\mathbf{M}$ & 11 & 128 & + & + \\
\hline 2 & 54 & $\mathbf{F}$ & 19 & 512 & $\mathbf{N}$ & + \\
\hline 3 & 43 & $\mathrm{~F}$ & 14 & 256 & $\mathrm{~N}$ & + \\
\hline 4 & 51 & $\mathbf{F}$ & 7 & 1024 & + & $-\dagger$ \\
\hline 5 & 62 & $\mathrm{~F}$ & 5 & 128 & $\mathbf{N}$ & + \\
\hline 6 & 65 & $\mathrm{~F}$ & 10 & 32 & - & + \\
\hline 7 & 57 & M & 6 & 2048 & - & - \\
\hline 8 & 59 & $\mathbf{M}$ & 7 & 2048 & $\mathbf{N}$ & - \\
\hline 9 & 59 & $\mathrm{~F}$ & 14 & 2048 & - & - \\
\hline 10 & 59 & $\mathbf{M}$ & 1 & 64 & - & - \\
\hline 11 & 64 & $\mathrm{~F}$ & 19 & Negative* & + & + \\
\hline 12 & 50 & $\mathrm{~F}$ & 7 & 256 & - & - \\
\hline
\end{tabular}


Table II Particulars of 24 episodes of infection in twelve patients with rheumatoid arthritis

\begin{tabular}{|c|c|c|c|c|c|c|c|}
\hline \multirow{2}{*}{$\begin{array}{l}\text { Patient } \\
\text { no. }\end{array}$} & \multirow{2}{*}{$\begin{array}{l}\text { Infection } \\
\text { no. }\end{array}$} & \multirow[t]{2}{*}{ Type and site of infection } & \multicolumn{2}{|l|}{ Organism } & \multirow{2}{*}{$\begin{array}{l}\text { Max. } \\
\text { temperature } \\
\left({ }^{\circ} \mathrm{F} .\right)\end{array}$} & \multirow{2}{*}{$\begin{array}{l}\text { White cell } \\
\text { count }\end{array}$} & \multirow[t]{2}{*}{ Outcome } \\
\hline & & & Identity & $\begin{array}{l}\text { Recovered } \\
\text { from }\end{array}$ & & & \\
\hline 1 & 1 & $\begin{array}{l}\text { Pyarthrosis R elbow and } \\
\text { knee } \\
\text { Abscess L calf }\end{array}$ & $\begin{array}{l}\text { Pneumo- } \\
\text { coccus }\end{array}$ & Abscess & $\mathbf{N}$ & 25,800 & Recovered \\
\hline \multirow[t]{3}{*}{2} & 2 & $\begin{array}{l}\text { Pyarthrosis R knee } \\
\text { Septicaemia } \\
\text { Endocarditis }\end{array}$ & $\begin{array}{l}\text { Staph. } \\
\text { aureus }\end{array}$ & $\begin{array}{l}\text { R knee } \\
\text { Blood }\end{array}$ & $104 \cdot 0$ & 15,900 & Recovered \\
\hline & 3 & Abscess R leg & $\begin{array}{l}\text { Staph. } \\
\text { aureus }\end{array}$ & Abscess & $100 \cdot 0$ & 7,600 & Recovered \\
\hline & 4 & Septicaemia & $\begin{array}{l}\text { Strept. } \\
\text { viridans }\end{array}$ & Blood & $102 \cdot 5$ & 4,600 & Recovered \\
\hline \multirow[t]{4}{*}{3} & 5 & Abscess $L$ thigh & $\begin{array}{l}\text { Staph. } \\
\text { aureus }\end{array}$ & Abscess & $99 \cdot 0$ & 8,000 & Recovered \\
\hline & $\begin{array}{l}6 \\
7 \\
8\end{array}$ & $\begin{array}{l}\text { Ovarian abscess } \\
\text { Abscess } L \text { buttock } \\
\text { L pyonephrosis and }\end{array}$ & $\begin{array}{l}\circ \\
\circ \\
\text { Proteus }\end{array}$ & $\overline{\overline{-}}$ & $\begin{array}{r}99 \cdot 0 \\
102 \cdot 0 \\
102.0\end{array}$ & $\begin{array}{r}8,500 \\
15,100 \\
\mathrm{~N}\end{array}$ & $\begin{array}{l}\text { Recovered } \\
\text { Recovered } \\
\text { Recovered }\end{array}$ \\
\hline & 9 & $\begin{array}{l}\text { R pyelonephritis } \\
\text { Septicaemia }\end{array}$ & $\begin{array}{l}\text { mirabills } \\
E . \text { coli }\end{array}$ & $\begin{array}{l}\text { Urine } \\
\text { Blood }\end{array}$ & $103 \cdot 0$ & 22,700 & Recovered \\
\hline & 10 & $\begin{array}{l}\text { Empyema of gallbladder } \\
\text { Pelvic abscess }\end{array}$ & O & - & $100 \cdot 0$ & 24,900 & Died \\
\hline \multirow[t]{4}{*}{4} & 11 & $\begin{array}{l}\text { Empyema } \\
\text { Suppurative pericarditis }\end{array}$ & $\begin{array}{l}\text { Staph. } \\
\text { aureus }\end{array}$ & $\begin{array}{l}\text { Blood } \\
\text { Pleural } \\
\text { fluid } \\
\text { Pericardial } \\
\text { fluid }\end{array}$ & $103 \cdot 0$ & 14,200 & Recovered \\
\hline & 12 & Abscess R. thigh & $\begin{array}{l}\text { Candida } \\
\text { albicans }\end{array}$ & Abscess & $98 \cdot 0$ & 6,600 & Recovered \\
\hline & 13 & Actinomycosis of chin & $\begin{array}{l}\text { Actino- } \\
\text { myces bovis }\end{array}$ & Chin & $\mathbf{N}$ & 5,300 & Recovered \\
\hline & 14 & Septicaemia & $\begin{array}{l}\text { Proteus } \\
\text { mirabilis }\end{array}$ & Blood & $102 \cdot 4$ & 6,700 & Recovered \\
\hline 5 & 15 & Perinephric abscess & 0 & - & $\mathbf{N}$ & $\mathbf{N}$ & Died \\
\hline 6 & $\begin{array}{l}16 \\
17\end{array}$ & $\begin{array}{l}\text { Subdural abscess } \\
\text { Suppurative pericarditis }\end{array}$ & $\begin{array}{l}\text { Pseudo- } \\
\text { monas }\end{array}$ & $\begin{array}{l}\text { Pericardium } \\
\text { (PM) }\end{array}$ & $\begin{array}{r}99 \cdot 6 \\
100 \cdot 0\end{array}$ & $\begin{array}{l}15,000 \\
10,300\end{array}$ & $\begin{array}{l}\text { Recovered } \\
\text { Died }\end{array}$ \\
\hline 7 & 18 & $\begin{array}{l}\text { Empyema } \\
\text { Pyarthrosis both shoulders }\end{array}$ & $\begin{array}{l}\text { Staph. } \\
\text { aureus }\end{array}$ & $\begin{array}{l}\text { Empyema } \\
\text { Joints (PM) }\end{array}$ & $98 \cdot 4$ & 10,400 & Died \\
\hline 8 & 19 & $\begin{array}{l}\text { Pneumonia } \\
\text { Cerebral abscess }\end{array}$ & 0 & - & $99 \cdot 0$ & 10,200 & Recovered \\
\hline 9 & 20 & Lung abscess & O & & $\mathbf{N}$ & 7,900 & Recovered \\
\hline 10 & 21 & $\begin{array}{l}\text { Empyema } \\
\text { Purulent tendon sheath } \\
\text { infection }\end{array}$ & $\begin{array}{l}\text { Pneumo- } \\
\text { coccus }\end{array}$ & $\begin{array}{l}\text { Pleual fluid } \\
\text { Sputum }\end{array}$ & $102 \cdot 0$ & 17,100 & Recovered \\
\hline \multirow[t]{2}{*}{11} & 22 & $\mathrm{~L}$ perinephric abscess & Staph. & Abscess & $103 \cdot 0$ & 4,300 & Recovered \\
\hline & 23 & $\begin{array}{l}\text { Pneumonia with abscess } \\
\text { formation }\end{array}$ & $\begin{array}{l}\text { Staph. } \\
\text { aureus }\end{array}$ & Sputum & $102 \cdot 0$ & 10,900 & Recovered \\
\hline 12 & 24 & Empyema & $\begin{array}{l}\text { Strepto- } \\
\text { coccus }\end{array}$ & Pleural fluid & $101 \cdot 0$ & 59,900 & Recovered \\
\hline
\end{tabular}


(1)

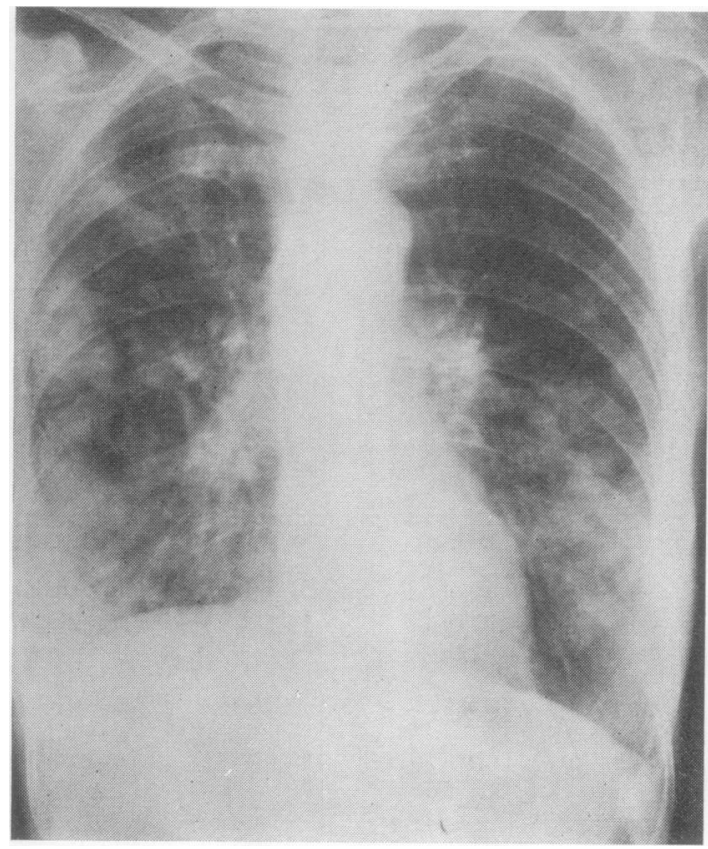

(3)

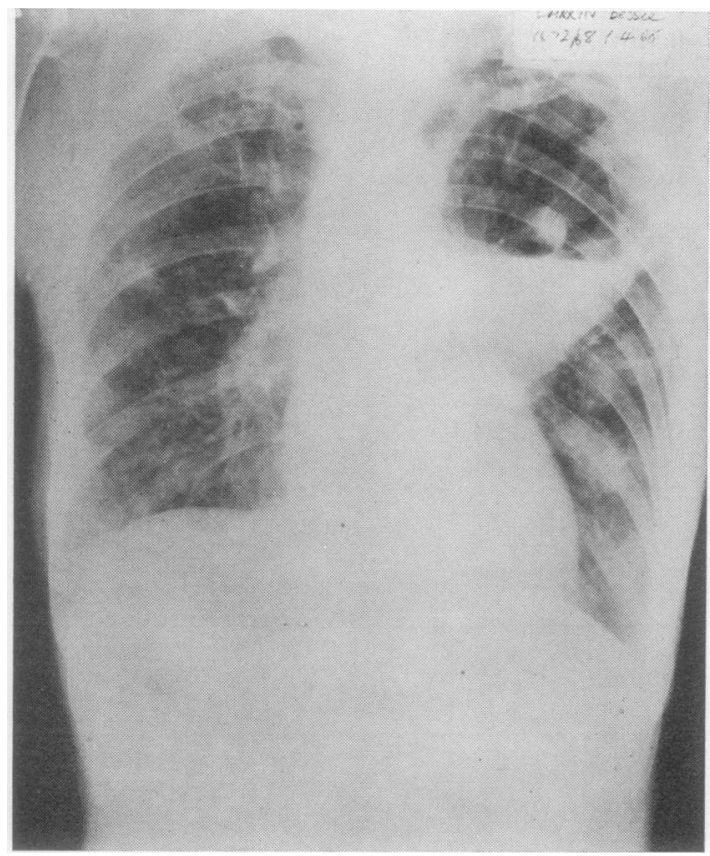

(2)

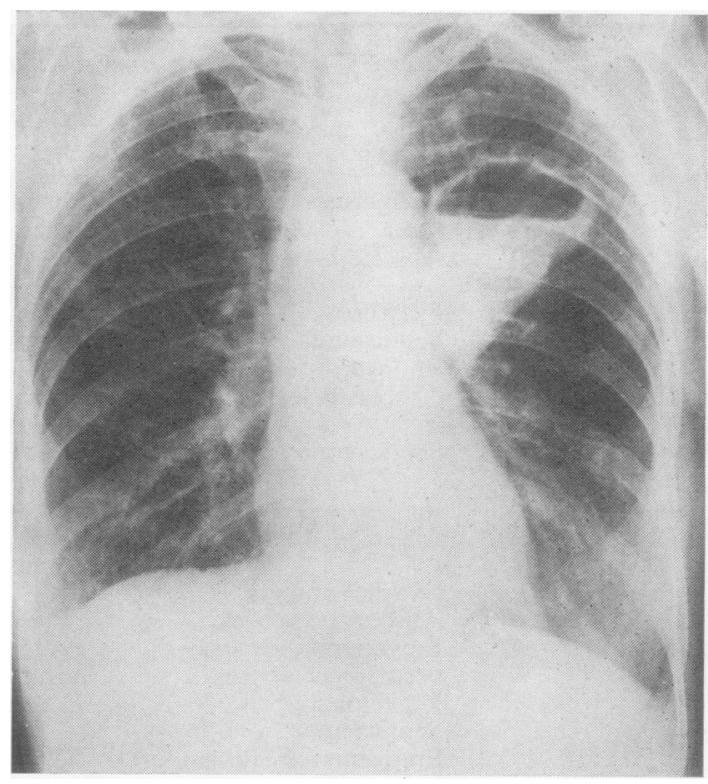

(4)

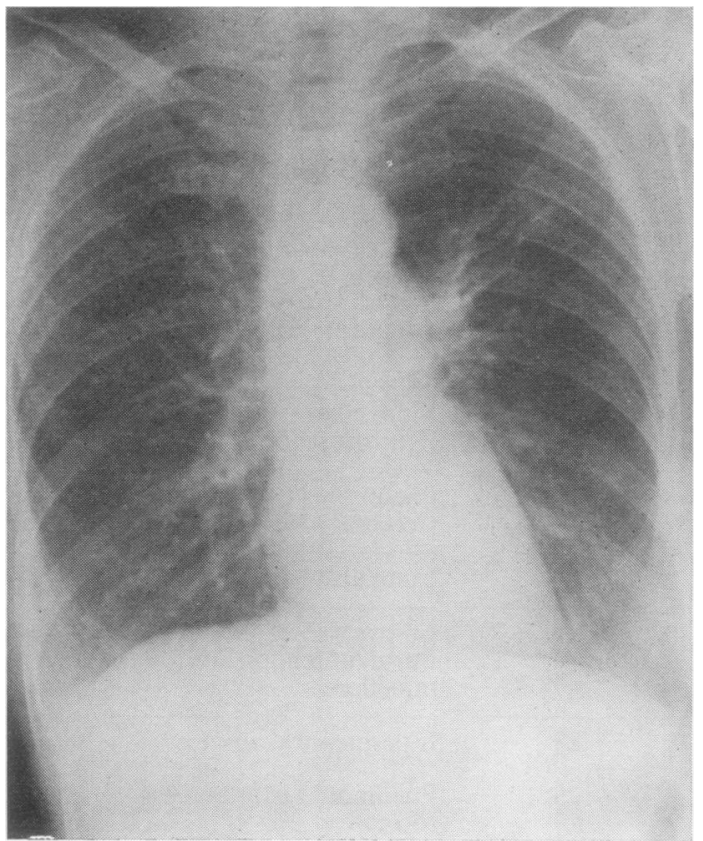

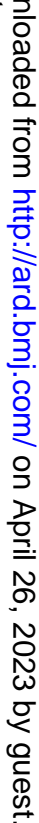

FIGS 1 to 4 Serial chest $x$ rays, showing staphylococcal pneumonia (Fig. 1), the development of a lung abscess (Figs 2 and 3), and its spontaneous disappearance (Fig. 4)

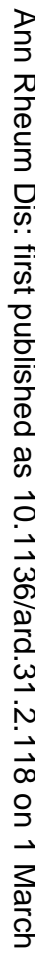

๑ 응 흘 
She now remains well with a normal blood count, but is bedevilled by recurrent shin ulcers which have recurred in the last 10 years.

In patients receiving steroid therapy, collapse due to infection can be mistakenly attributed to acute adrenal insufficiency:

Case 4, a woman now aged 51 years, was admitted as an emergency having collapsed at home (Episode 14). She was in a state of shock with a systolic blood pressure of $70 \mathrm{~mm}$. $\mathrm{Hg}$. She had been taking prednisone $9 \mathrm{mg}$. daily for 2 years, but had been vomiting for 2 days and was unable to take tablets. The plasma cortisol was $76 \cdot 3 \mu \mathrm{g} . / \mathrm{ml}$. and blood cultures grew Proteus mirabilis.

In several cases the infection was clinically silent for long periods and was sometimes found only at post mortem examination.

Case 7, a man aged 57 years, was admitted with severe rheumatoid arthritis and increasing breathlessness due to fibrosing alveolitis and cardiac failure (Episode 18). His condition gradually deteriorated and he died.

When the skin over the thorax was reflected at post mortem, a subcutaneous abscess was found communicating with an empyema. There was also bilateral pyarthrosis of the shoulder joints, unsuspected in life.

In some cases the recognition of the correct diagnosis was delayed because other pathological processes, particularly malignancy, were considered more likely. It is clear that, in patients with rheumatoid arthritis, infection must always be prominent in the differential diagnosis.
Case 8, a man aged 59 years, was admitted with left-sided epileptiform fits and was subsequently found to have a left hemiplegia. There was clubbing of the fingers and a chest $x$ ray showed collapse and consolidation of the right upper lobe. A diagnosis of bronchial carcinoma with cerebral metastasis was made. He was treated with antibiotics with some clearing of the radiological changes in the chest (Figs 1 to 4). A right carotid arteriogram showed a large fronto-parietal mass; at burr-hole biopsy $18 \mathrm{ml}$. pus were aspirated from a abscess cavity (Episode 19).

\section{Discussion}

On the basis of their experience, Kellgren, Ball, Fairbrother, and Barnes (1958) emphasized the importance of aspirating rheumatoid joints if there was any suspicion of pyarthrosis. Their series showed that fever and leucocytosis were not always present and our cases support this. We suggest that infections should be considered as a likely cause of deterioration or of the development of other complications in patients with severe rheumatoid arthritis. Localized infection may be completely silent and must therefore be sought. Serious infection is not confined to patients receiving steroid therapy.

\section{Summary}

24 infective episodes in twelve patients with rheumatoid arthritis are described. The cases illustrate the importance of infection as a cause of deterioration and death in patients with rheumatoid arthritis.

\section{References}

Cobb, S., ANDerson, F., AND Bauer, W. (1953) New Engl. J. Med., 249, 553 (Length of life and cause of death in rheumatoid arthritis)

Goldfine, L. J., Stevens, M. B., Mais, A. T., And Shulman, L. E. (1965) Ann. rheum. Dis., 24, 153 (Clinical significance of the L.E.-cell phenomenon)

KAY, A. (1967) Lancet, 2, 152 (Infection in rheumatoid arthritis) [Letter]

Kellgren, J. H., Ball, J., Fairbrother, R. W., and Barnes, K. L. (1958) Brit. med. J., 1, 1193 (Suppurative arthritis complicating rheumatoid arthritis)

WALKER, W. C. (1967) Quart.J. Med., 36, 239 (Pulmonary infections and rheumatoid arthritis) 